relatively high temperature of a star by some observers, in consequence of the production of these lines in arc spectra under certain special conditions. The recent work of $\mathrm{Mr}$. C. de Watteville ${ }^{2}$ on flame spectra in relation to spark spectra obtained with and without self-induction, however, appears to be entirely in harmony with the result derived from stellar inquiries by Sir Norman Lockyer.

At present, then, the evidence available appears to favour the view that the chemical differences indicated in the different groups of stars are due to differences of temperature, and that successively higher stages of heat are indicated by the predominance of metallic, proto-metallic, and gaseous lines. Thus, although further researches on some points are needed, it is very probable that the new classification correctly exhibits the relative temperatures of the various stellar groups, besides giving exhaustive definitions and providing a convenient nomenclature. At the same time, the sequence of phenomena indicated in the classification seems strongly to support the dissociation hypothesis.

A. FOWLER.

\title{
THE FALKLAND ISLANDS
} AND THEIR FAUNA.

MR. RUPERT VALLENTIN, who has spent many years in the Falklands, where he has been an assiduous observer and collector of the fauna and flora, contributes an excellent account, illustrated by photographs, of those remote islands to the third part of vol. xlviii. of the Memoirs of the Manchester Literary and Philosophical Society, of which his article forms No. 23. The author alludes in the first place to the celebrated stone-rivers, which consist of slowly moving blocks of quartzite between banks of peat. In Mr. Vallentin's opinion the stones forming these "rivers" had approximately attained their present position before the formation of the peat, and the "rivers"

ing, the sole remnant of the covering of vegetation is a mass of bog-balsam (Bolax globaria), as shown in Fig. $x$, which, owing to its long tapering root, can obtain nourishment after the soil which supported other plants has been washed away. Very similar "stone-rivers" exist in parts of the Himalaya.

Apparently the Falklands are by no means the desolate

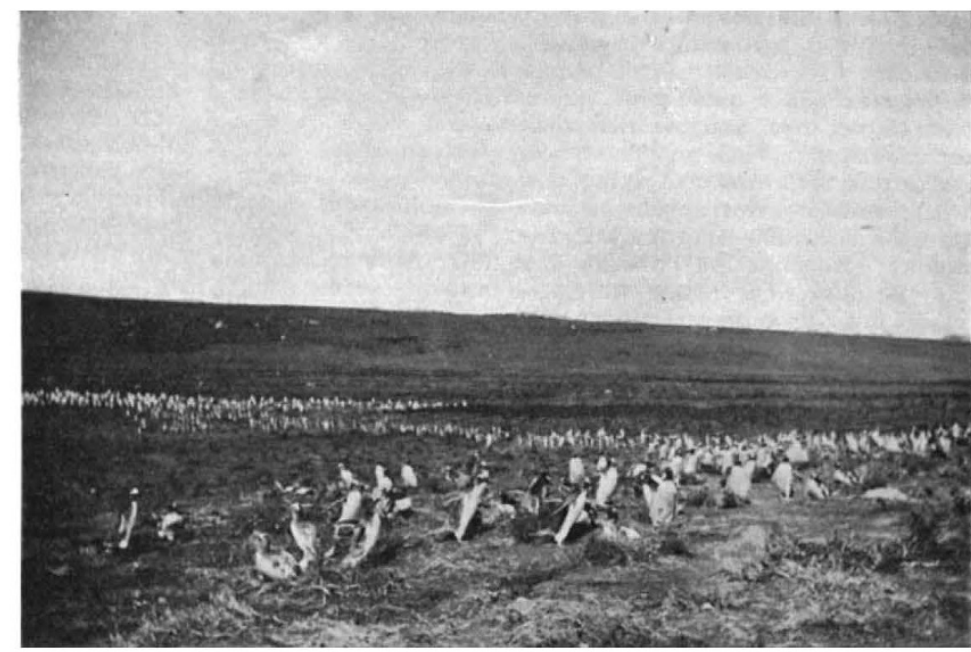

Fig, 2.--Gentu Penguins on the Falklands. The birds in the background are running to the shore.

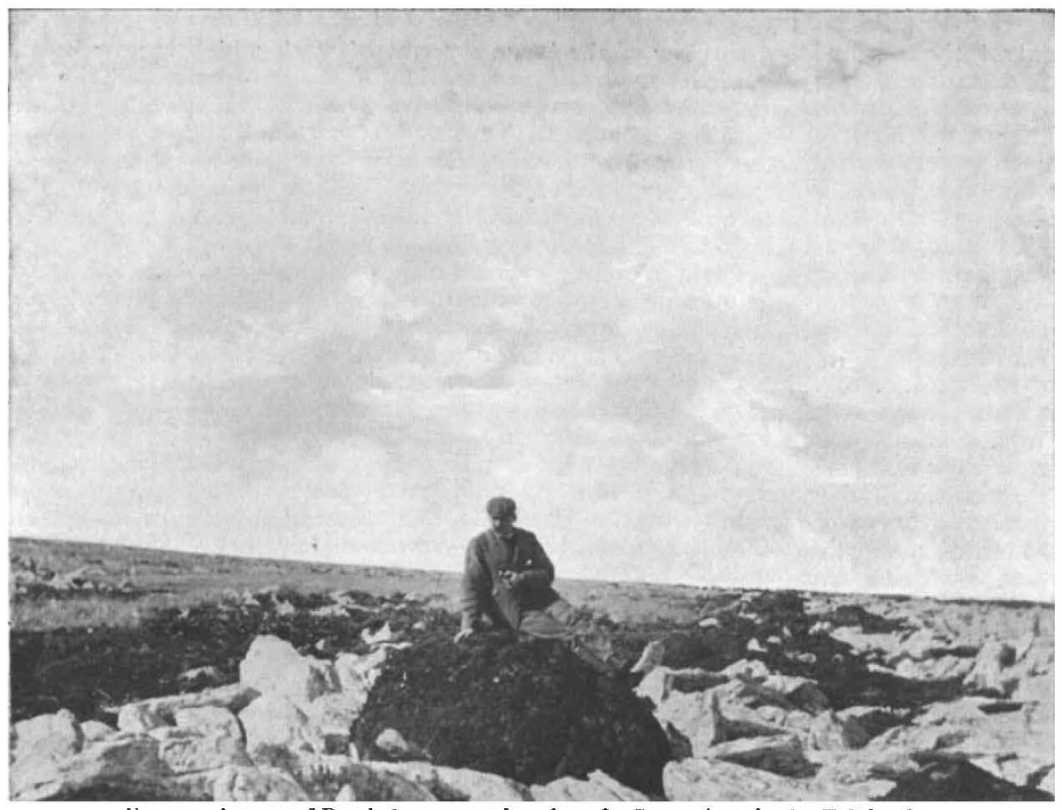

Fig. I.-A mass of Bog-balsam near the edge of a Stone-river in the Falklands.

spots we are often prone to imagine, the vegetation being locally abundant, and the shores of the estuaries and coves on part of West Falkland being fringed with bushes of the attractive Falkland box (Veronica decurrata), which has a beautiful and highly scented flower. With the aid of abundant manure, many English vegetables can be grown in sheltered spots.

With regard to the fauna, the most interesting statement is the one to the effect that, so far as the author could ascertain, the Falkland Island wolf (Canis antarcticus) is now completely exterminated. This latest addition to the list of animals extirpated in recent years by human agency is the more to be regretted seeing that this wolf, or fox as it used to be called by the settlers, is an extremely interesting animal from the point of view of geographical distribution, and one that is probably very insufficiently represented in our museums. According to Prof. Huxley's paper on the dentition of the Canidæ, published in the Zoological Society's Proceedings for I880, the Falkland Island wolf is closely allied to the North American coyote, the remarkable feature connected with this resemblance being that there are no true wolves in either Central or South America. The British Museum has one mounted skin of the Antarctic wolf in the exhibition galleries, and there are two skeletons in the store collection. Strychnine poisoning appears to have brought about the extermination of this wolf, the last survivor have been produced by the denudation of the peat. In of which seems to have been killed so long ago as 1876 . every "stone-river" islets of vegetation remain near the margins, these being most luxurious where the denudation has been recent. Where the denudation is of long stand-

1 Roy. Soc. Proc., vol. lxxiv. p. 85 (rgo4).

Birds form by far the most important portion of the terrestrial vertebrate fauna of the Falklands, and among these penguins, of three species, and "mollymauks," or lesser albatrosses, are numerically the most abundant. Mr.

No. I 826 , VOL. 70$]$ 
Vallentin's article is illustrated by a photograph of a "rookery" of rock-hopper penguins (Eudyptes chrysocome), showing the myriads in which these birds congregate on the coasts, and by a second (herewith reproduced) of a much smaller assemblage of gentu penguins (Pygosceles taeniata). An interesting fact in connection with the habits of the rock-hoppers is that the smooth surfaces of the hard igneous rock over which these penguins have passed for generations are not only highly polished, but are marked by irregular groovings made by their claws. These scratches are usually about 3 inches in length, and may be as much as a quarter of an inch in depth. Apparently such a polished and striated rock-surface might well be attributed to ice-action. A striking feature about such a rookery is the number of dying and maimed birds to be met with; such injuries appear to have been inflicted by seals or sea-lions. The enormous number in which the "mollymauks" frequent the Falkland and other Antarctic islands may be inferred from the statement that on one occasion a vessel arrived at the main port with a cargo of 10,000 eggs of this species. Mr. Vallentin found these beautiful birds so tame and confiding that they allowed themselves to be stroked by his hand as he admired the softness of their plumage and its spotless condition. How these birds keep themselves clean amid the liquid filth of a rookery is little short of a marvel.

R. L.

\section{THE ST. LOUIS INTERNATIONAL ELECTRICAL CONGRESS.}

THIS congress, during its five working days, considered about 160 papers on electrical subjects. In fact, so large was the number of papers and so wide the range of subjects of which they treated, that it may be said that there is no branch of electrical science which was not referred to at one time or another during the meetings. Nevertheless, the chief scientific interest in the proceedings centred round a few subjects, namely, units and standards, radio-activity, wireless telegraphy, and the electric arc. Of the engineering papers, those on the alternating current motor, the steam turbine, and high tension transmission attracted most attention. There were also numerous papers on electrochemical and electrotherapeutical subjects, which will not be referred to here.

The joint discussion by Section A, general theory, and Section B, general applications, on units and standards was opened with papers by Prof. Ascoli (systems of electric units), Profs. Carhart and Patterson (absolute value of the E.M.F. of Clark and Weston cells), and Dr. Wolff (international electric units). The subject divided itself into two parts :(I) the true value of the volt and ampere; (2) which of these should be represented by a material standard, and the nature of that standard. During the discussions the naming of the magnetic units was also considered.

Upon the question of the true value of the volt and ampere there was practical unanimity of opinion that the true value of the volt ( $10^{8}$ C.G.S. units) is such that the E.M.F. of a standard Clark cell at $\mathrm{I}^{\circ} \mathrm{C}$. is very much nearer 1.433 volts than I.434, the present legal value. Profs. Carhart and Patterson, in describing the dynamometer with which they are making a re-determination of the ampere, stated that though the experiments were not sufficiently advanced to give a definite value, the results so far obtained made the E.M.F. of the Clark cell about 1.433 volts, accepting the $\mathrm{ohm}$ as correct. In this connection Mr. Trotter's results, mentioned by Dr. Glazebrook, are of great interest. Mr. Trotter has recently made a determination of the E.M.F. of the Clark cell at the Board of Trade laboratory in terms of the standard ampere and standard ohm, and finds the value to be $x .4329$ volts at $15^{\circ} \mathrm{C}$. It would thus appear that the voltage of a normal Clark cell, determined in terms of our standard ampere and ohm, is nearly I/Io of I per cent. less than the legalised value. The Reichsanstalt take the value of the Clark cell at $I \cdot 4328$ volts. It is of interest to note that the present legal value of $x .434$ appears to be almost exactly correct at $14^{\circ} \mathrm{C}$. instead of $15^{\circ} \mathrm{C}$.

$\mathrm{Mr}$. Barnes, in his paper on the mechanical equivalent of heat measured by electrical means, which contains a very careful comparison of the results obtained both by the electrical and mechanical methods, takes the Clark cell as No. 1826 , vol. 70$]$
I. 43325 volts, and then finds that the "results by the continuous electrical method is brought into absolute agreement with the mean of the mechanical measurements," and he gives the value of the mechanical equivalent as 4.186 joules in terms of the mean calorie between $0^{\circ}$ and $100^{\circ}$.

The standards which are to represent the fundamental electrical units raised quite another set of questions, the main desiderata for these standards being that they should be both permanent and reproducible to a high degree of accuracy. No one appeared anxious to quarrel in any way with the standard mercury ohm, and the agreement of the standards lately made by the National Physical Laboratory, both with one another and with those constructed by the Reichsanstalt, shows that this standard is reproducible to a few parts in 100,000. Accepting the present ohm standard, it is only necessary to legalise a standard for either the ampere or the ohm, as the three units are connected by Ohm's law. Prof. Carhart and Dr. Wolff urged the desirability of defining the voit in terms of a cell, preferably the cadmium cell, and the ampere in terms of the volt and $\mathrm{ohm}$, the advantages being that the standard cell is very generally used in practical measurements both of potential difference and current, and that the cells are reproducible to a high degree of accuracy. Dr. Glazebrook pointed out that the greater simplicity of the chemical changes in the deposition of silver gave promise of its being an even more accurate standard for the ampere.

Prof. Carhart and Mr. Hulett, in their paper on a study of the materials used in standard cells and their preparation, trace the difficulties with cells both of the Clark and Weston (cadmium) type to the mercurous sulphate; they describe an electrolytic method of preparing it, and they strongly emphasise the importance of avoiding hydrolysis of the mercurous sulphate. In a table in the paper they give the results obtained with fourteen cadmium cells made according to their method, from which it appears that the maximum difference between the voltages of in dividual cells and between the voltages of the cells during the whole seven months that the tests lasted did not exceed 5 parts in 100,000 , so that, taking any cell at any time during the tests, its voltage could be depended on to within \pm 0.03 millivolt of the mean voltage. Similar excellent results have been obtained by Mr. Smith at the National Physical Laboratory (report to British Association, Cambridge).

In view of the large amount of work which is now being carried out on the preparation of standard cells and the redetermination of the ampere, the general feeling of the meeting seemed to be that international action to correct the error in the volt should be postponed, although one speaker urged that the error of o.r per cent. in the volt had become of serious commercial importance in the life tests of incandescent lamps.

Prof. Wolff's paper, which dealt largely with the legal definitions of the fundamental units adopted by various nations, pointed out the great differences which exist, and the necessity of rendering them all uniform.

On the subject of naming the magnetic units there was very little discussion; the question of $4 \pi$, of course, came up, and was discreetly left on one side, most of the meeting agreeing with Dr. Kennelly that it is better to let well alone, and that no very great practical advantage would result from the change. The views of the I.E.E. delegates, that if any magnetic units were named they should be those proposed by Dr. Kennelly, viz. the C.G.S. units of magnetic potential (already called the Maxwell at the Paris congress), total magnetic flux, and magnetic reluctance, met with pretty general acceptance. The other proposal made by Dr. Kennelly, namely, to add the prefix " ab" or "abs" to the names of the practical units to forn names for the corresponding C.G.S. units in the electromagnetic and electrostatic systems, so that " abvolt" would be the name for the C.G.S. unit of difference of potential in the electromagnetic system, and absampere for the C.G.S. unit of current in the electrostatic system, led to no discussion, the I.E.E. delegates simply expressing their disapproval of this proposal, which made the same prefix have different numerical values according to the name it preceded.

The chamber of Government delegates, to which Great Britain appointed at the last moment Colonel Crompton. 